\title{
Environmental Impacts of Tartaric Stabilisation Processes for Wines using Electrodialysis and Cold Treatment
}

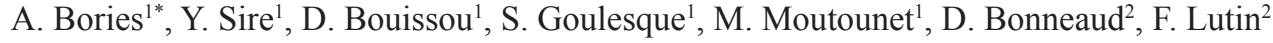 \\ (1) INRA, UE 0999, Unité Expérimentale de Pech Rouge, 11430 Gruissan, France \\ (2) EURODIA INDUSTRIE S.A., ZI Saint Martin, 84120 Pertuis, France
}

Submitted for publication: February 2011

Accepted for publication: May 2011

Key words: tartaric stabilisation, electrodialysis, reverse osmosis, cold treatment, wastewaters, energy, wastes, eco-design

\begin{abstract}
The environmental impacts of the two tartaric stabilisation methods used for wines, electrodialysis and cold treatment, were studied by determining water consumption (for the process and cleaning), waste produced (organic load and the composition of wastewater and residues) and energy consumption, at the pilot stage and in wineries. Thanks to an online treatment of electrodialysis brines by reverse osmosis (industrial facility that treats $30 \mathrm{hL}$ wine/h), the recycling of permeates led to a $65 \%$ reduction in water consumption, the volume of which represented only $3.9 \%$ of the wine treated. When washing and cleaning water from the ED-RO system was taken into account, overall water consumption was $5.5 \mathrm{~L} / \mathrm{hL}$ wine. The presence of ethanol, due to an osmotic phenomenon with no loss of wine volume, and tartaric acid in the brines contributes to the organic load of the brine, with a COD of close to $8.4 \mathrm{~g} \mathrm{O} / \mathrm{L}$. Overall electrical energy consumption for stabilisation by electrodialysis $(0.21 \mathrm{kWh} / \mathrm{hL})$ turned out to be eight times lower than that of cold stabilisation. An evaluation of cold stabilisation effluents revealed that $66.6 \%$ of the COD discharged came from the diatomaceous earth (DE), $21.8 \%$ from the washing of the filter and $11.4 \%$ from the washing of the cold treatment tank. The production of used DE was $2.64 \mathrm{~g}$ (wet weight)/L of wine, and the ethanol present in the DE waste represented a loss in wine volume of $0.14 \mathrm{~L} / \mathrm{hL}$.
\end{abstract}

\section{INTRODUCTION}

The reduction of the environmental impacts of the wine sector includes the eco-design of environmentally-friendly winemaking processes, the determination of activities that generate effluents and waste, as well as input consumption and resource management (water, energy, reagents).

Winemaking operations - vinification (clarification of the must and racking, devatting) and stabilisation (clarification, filtration, tartaric stabilisation, bottling) generate wastewater (washing and process water), the sum of which is referred to as winery wastewater. An assessment of pollution loads revealed a wide variation in winery wastewater volumes, depending on the winery: 0.5 to 10 $\mathrm{L} / \mathrm{L}$ of wine, with an average value of approximately $1 \mathrm{~L} / \mathrm{L}$ of wine (Mourgues \& Maugenet, 1972; Maugenet, 1978; Picot, 1992; Duarte et al., 1998; Lemiere et al., 1998; Picot \& Cabanis, 1998; Rossi et al., 1998; Viaud et al., 1998; Sheridan et al., 2004; Colin et al., 2005; Rochard, 2005; Vogdt \& Schleenstein, 2006). Vinification produces almost two-thirds of the annual wastewater volume. Nevertheless, vinification methods reveal wide disparities in terms of waste (Bories \& Sire, 2010): the specific pollution coefficient for liquid-phase vinification (white and rosé wines and thermovinifications) is as much as $40 \%$ higher than that of solid-phase vinification (red wine) as a result of must racking and filtration operations that generate waste that is rich in organic matter (sugar, lees from musts). Waste generated by some unit operations - washing of the vats and filters - has been quantified on a unit basis (Grenier et al., 1998; Duarte et al., 2004).

Tartaric stabilisation is essential to satisfy the quality criteria of wines (Saint-Pierre et al., 1998). Tartaric stabilisation processes use subtractive methods - crystallisation of potassium hydrogen tartrate by cold treatment (Ferenczi et al., 1982; Peng et al., 1996), extraction of tartaric acid and potassium using a membrane process (electrodialysis) (Cottereau, 1989; Moutounet \& Escudier, 1991; Moutounet et al., 1997), use of ion exchangers (Hernández \& Mínguez, 1997; Gómez Benítez et al., 2002) - or additive methods such as the addition of metatartaric acid (Blouin, 1982), mannoproteins (Moine-Ledoux et al., 1997; Moutounet et al., 1999) or carboxymethylcellulose (Marchal et al., 2009; 2010; Moutounet et al., 2010a).

Subtractive tartaric stabilisation methods entailing cold treatment, a widely used process, and electrodialysis, a technique that is becoming increasingly popular, make it possible to avoid the addition of additives to wines.

Cold stabilisation, the most commonly used technique because it is the oldest, has been broken down into several 
systems: stabulation (batch), continuous contact, with clarification of the wines by filtration or centrifugation. Filtration of cold-processed wines on diatoms (diatomaceous earth) leads to environmental disadvantages linked to filtration residues and electrical energy consumption. Rich in organic matter - potassium hydrogen tartrate, lees and occluded wine - as well as in mineral matter (silica), filtration wastes require specific treatment (disposal in a landfill, composting). Chilling of the wine at negative temperatures $\left(-2\right.$ to $\left.-4^{\circ} \mathrm{C}\right)$ and its maintenance over several days (four to 12 days) require electrical energy consumption of 1 to 1.7 kWh/hL wine (Langlois, 1992; Gómez Benítez et al., 2002; Low et al., 2008).

In contrast with cold treatment, which ensures the stabilisation of wines without taking the degree of instability of the wine into account, tartaric stabilisation using an electromembrane process makes it possible to adjust the stabilisation treatment rate precisely (Moutounet et al., 1999; 2010b). This relatively recent process provides environmental benefits in comparison with cold stabilisation: elimination of diatomaceous earth and lower energy consumption. Nevertheless, most of the data available in the literature on the eco-balance of tartaric stabilisation of wines by electrodialysis (water and energy consumption) are based on studies carried out at the pilot level (Moutounet \& Escudier, 1991; Gómez Benítez et al., 2002) or by simulation (Low et al., 2008).

In this study, water consumption, effluent and waste balances, as well as their composition, were determined at the industrial and pilot scale for both of the subtractive methods used for tartaric stabilisation: electrodialysis and cold treatment. The reduction of water consumption for tartaric stabilisation by electrodialysis was studied using a reverse osmosis treatment of the brine with recycling of the permeate. The pollution flows generated from the tartaric stabilisation of wines were compared to those of vinification operations.

\section{MATERIALS AND METHODS}

Tartaric stabilisation by electrodialysis was carried out on a continuous basis with two devices:

An INRA/EURODIA pilot device, including 150 elementary cells and with a treatment capacity of $15 \mathrm{hL}$ wine $/ \mathrm{h}$

A semi-automatic EURODIA industrial unit, including two stacks of 150 cells, with a total treatment capacity of $30 \mathrm{hL}$ wine/ $\mathrm{h}$.

The brines produced for each series of measurements were collected in tanks to measure the volume and to take samples. To treat the brines generated by the industrial electrodialysis device, an osmosis unit (reverse osmosis, RO) was coupled with a brine circuit and had the following characteristics: four osmosis membranes (ESPA2-4040, NITTO DENKO Corp., Osaka, Japan) with a total active area of $31.6 \mathrm{~m}^{2}$, a salt rejection of $99.6 \%$, a maximum pressure of $25.10^{5} \mathrm{~Pa}$ and an operating pressure of approximately $15.10^{5} \mathrm{~Pa}$, with a feed flow of 400 to $450 \mathrm{~L} / \mathrm{h}$ (Fig. 1). The permeate from the osmosis unit was recycled in the brine tank of the electrodialysis unit, thus serving as makeup water, and the retentate, concentrated in tartrate salts, was evacuated by the overflow outlet of the feed tank of the osmosis unit. The overflow was collected in several tanks to measure the volume and to take samples.

Input measurements were taken using mechanical volumetric meters installed on the soft water, hot water and system water circuits, and graduated gauges were used for the nitric acid and sodium hydroxide containers. Volumes evacuated on the basis of the different test configurations - electrodialysis alone, electrodialysis + reverse osmosis, cleaning-in-place (CIP) for the electrodialysis and osmosis units - were collected and measured separately in a gauging tank. CIP took place every 12 hours during the operation of the electrodialysis and reverse osmosis units. Measurement of electrical consumption was carried out using a clamp-on ammeter connected to the feed cable of the control panel of both devices (electrodialysis and reverse osmosis).

Cold tartaric stabilisation was carried out on a batch of white wine from Champagne winery (Reims, France) with a volume of $825 \mathrm{hL}$, maintained at $-4^{\circ} \mathrm{C}$ for seven days, with the seeding of $3 \mathrm{~g} / \mathrm{L}$ of cream of tartar. The wine was filtered through a horizontal plate filter (Filtrox-O-MAT 110/1300 filter, Filtrox, Beaune, France) with a capacity of 1470 L and a filtering area of $15.6 \mathrm{~m}^{2}$ (24 elements with an area of $0.65 \mathrm{~m}^{2}$ ), operating at a pressure of $6.10^{5} \mathrm{~Pa}$. Washing waters from the wine tank and the filter were collected separately in tanks in order to measure the volume and to take an average sample. Diatomaceous earth was specifically recovered in a bin to be weighed and sampled.

Measurements of $\mathrm{pH}$ and conductivity were taken with a WTW MultiLine P4 or a Multi1970i pH/conductivity meter, equipped with WTW TetraCon $325^{\circledR}$ probes to measure conductivity and WTW SenTix41 probes to measure $\mathrm{pH}$. An analysis kit (reagent tubes, heating block and colorimetric assaying) was used to measure the COD according to the standardised NANOCOLOR ${ }^{\circledR}$ COD 1500 method developed by Macherey-Nagel (Macherey-Nagel GmbH \& Co, KG, Düren, Germany) and corresponding to the DIN-ISO-15705 standard.

Tartaric, malic, lactic and acetic acid assays were done by HPLC analysis, with a BIORAD Aminex HPX-87H column $(7.8 \times 300 \mathrm{~mm})$, acidic water $\left(0.004 \mathrm{M} \mathrm{H}_{2} \mathrm{SO}_{4}\right)$ as the mobile phase, a flow of $0.5 \mathrm{~mL} / \mathrm{min}$ at $45^{\circ} \mathrm{C}$, a Waters 515 isocratic pump and a 717 automatic injector, and detection with a 2487 UV spectrophotometer $(210 \mathrm{~nm})$ (Waters, Milford, MA, USA). Sugars, ethanol and glycerol were assayed by HPLC under the same operating conditions as for separation, but with a Waters 2410 refractometric detector. Chromatographic data were gathered and integrated using EMPOWER software (Waters).

Cations (potassium, magnesium, sodium, calcium) were analysed by ion HPLC: Waters IC-Pak C M/D column (3.9 x $150 \mathrm{~mm}$ ), $0.1 \mathrm{mM} \mathrm{EDTA} / 3 \mathrm{mM} \mathrm{HNO}_{3}$ as the eluent, a flow of $1 \mathrm{~mL} / \mathrm{min}$ at room temperature, detection by a Waters 430 conductimeter and data processing using EMPOWER software.

Anions (sulphate, chloride, nitrate) were determined with the same HPLC device but with a Waters IC-Pak A column (4.6 x $50 \mathrm{~mm})$, a $1.3 \mathrm{mM}$ borate/gluconate buffer + $10 \%$ acetonitrile ( $\mathrm{vol} / \mathrm{vol})$ at $\mathrm{pH} 8.5$ as the mobile phase, and a flow of $1.2 \mathrm{~mL} / \mathrm{min}$. 


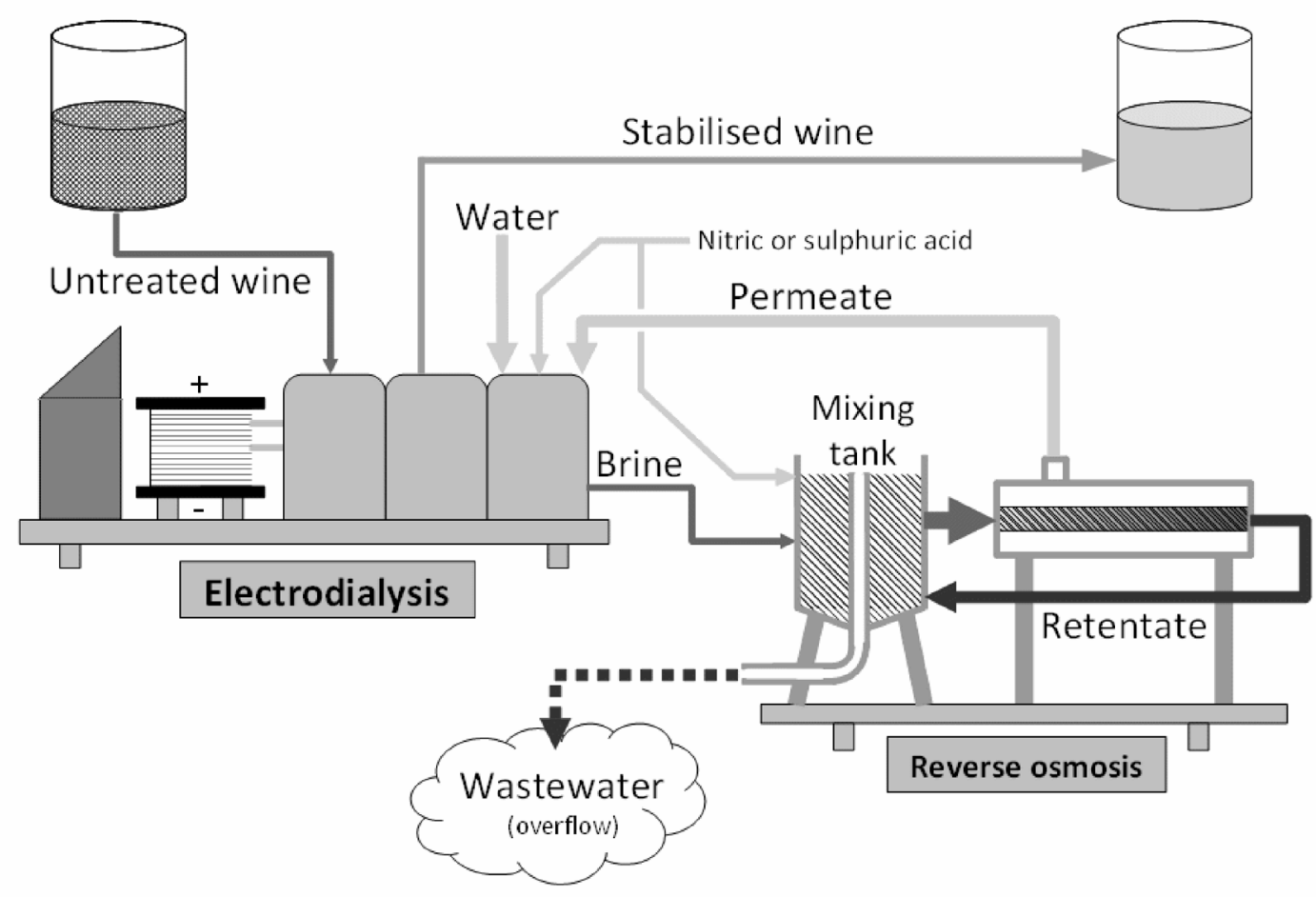

FIGURE 1

Flowchart of tartaric stabilisation by electrodialysis coupled with reverse osmosis treatment of the brine.

Diatomaceous earth was analysed after extraction with water ( $1 \mathrm{~g}$ wet soil/100 $\mathrm{mL}$ ultrapure water) under shaking in a beaker for $10 \mathrm{~min}$. After decantation, the aqueous phase was sampled for the analysis of the dissolved compounds (ethanol, potassium, etc.) according to the methods described above.

Eco-balances for tartaric stabilisation by electrodialysis and cold treatment were determined for different wines, the overall composition of which is given in Table 1.

\section{RESULTS AND DISCUSSION}

Tartaric stabilisation by electrodialysis

Composition of brines from tartaric stabilisation by electrodialysis (ED)

In the electrodialysis process, the constituents extracted from the wine by ion membranes are collected and concentrated in the brine circuit. In order to avoid any crystallisation, the concentration and $\mathrm{pH}$ of the brine are adjusted by adding water and acid. The characteristics of the brines produced are given in Table 2 .

The organic load, with a COD of close to $8.4 \mathrm{~g} \mathrm{O} / \mathrm{L}$, can be broken down into ethanol (40 to $67 \%$ of the COD), tartaric acid (6.8 to $3.7 \%$ of the COD), and secondary compounds (malic and lactic acid, etc.) (Table 2). It should be observed that the quantity of ethanol in the brines, 1.6 to $2.69 \mathrm{~g} / \mathrm{L}$, is equivalent to 0.02 to $0.03 \% \mathrm{vol} / \mathrm{vol}$ of the wine's alcohol content. This slight decrease in the ethanol content of the wine is the result of an osmosis phenomenon and the wine loss is insignificant.

Potassium is the main cation found in the brines ( 1.8 to 2 $\mathrm{g} \mathrm{K} / \mathrm{L})$. The major mineral anion in the brines depends on the
TABLE 1

Wine composition and corresponding tartaric stabilisation methods.

\begin{tabular}{|c|c|c|c|c|}
\hline Wine & $\mathbf{A}$ & B & $C^{*}$ & D* \\
\hline Type & White & White & Red & White \\
\hline $\begin{array}{l}\text { Tartaric } \\
\text { stabilisation }\end{array}$ & $\begin{array}{c}\text { ED, } \\
\text { ED+RO }\end{array}$ & ED & Cold & Cold \\
\hline $\mathrm{pH}$ & 3.55 & 3.60 & 3.62 & 3.01 \\
\hline $\begin{array}{l}\text { Conductivity } \\
(\mathrm{mS} / \mathrm{cm})\end{array}$ & 1.64 & 2.25 & 2.27 & 1.54 \\
\hline Alcohol (\% v/v) & 13.0 & 14.2 & 13.0 & 11.2 \\
\hline Tartaric acid $(\mathrm{g} / \mathrm{L})$ & 1.88 & 2.60 & 4.48 & 2.59 \\
\hline Malic acid (g/L) & 0.17 & 0.54 & 0.52 & 5.85 \\
\hline Lactic acid (g/L) & 3.42 & 0.91 & 1.55 & 0.36 \\
\hline Potassium (g/L) & 0.888 & 1.587 & 1.395 & 0.488 \\
\hline
\end{tabular}

* Samples analysed before filtration.

type of acid used to control the $\mathrm{pH}$ of the brine, the choice of which is determined by recommendations for wastewater treatment and their destination (Table 2).

\section{Reduction of water consumption as a result of treating} electrodialysis brines by reverse osmosis

During electrodialysis treatment, the brine composition is controlled and regulated ( $\mathrm{pH}$, conductivity) at thresholds determined by the addition of water and acid to ensure optimal conditions for extracting tartaric acid and potassium. Water consumption values found in the literature for the basic electrodialysis process ranged from 0.1 to $0.15 \mathrm{~L}$ water/L 
wine (Moutounet \& Escudier, 1991). However, these values were determined during process development and during finalisation in pilot facilities and prototypes (Moutounet et al., 1997).

In our study, the water consumption balance during tartaric stabilisation by electrodialysis was determined using an industrial electrodialysis facility (wine yield: $30 \mathrm{hL} / \mathrm{h}$, wine A) equipped with brine treatment by reverse osmosis, and coupled with electrodialysis by recycling of the permeates (Fig. 1). Water consumption decreased from $320 \mathrm{~L} / \mathrm{h}(0.106$
$\mathrm{L}$ water/L vine) when using the basic electrodialysis process (brines in lost water) to $113 \mathrm{~L} / \mathrm{h}$, the average of the values under stabilised conditions (for the period of time from 4 to 7 hours), when it was coupled with brine treatment by reverse osmosis and recycling of the permeate $(300 \mathrm{~L} / \mathrm{h})$ in the brine circuit (Fig. 2). Water consumption was reduced by $65 \%$ and represents $3.9 \mathrm{~L}$ water/ $\mathrm{hL}$ wine.

The increase of the conductivity of the retentate from 8 to $18 \mathrm{mS} / \mathrm{cm}$ underscores the phenomenon of brine concentration by reverse osmosis (Fig. 3). At the same

TABLE 2

Composition of brines from tartaric stabilisation by electrodialysis, with the $\mathrm{pH}$ controlled by nitric acid (wine $\mathrm{A}$ ) or by sulphuric acid (wine B).

\begin{tabular}{lcc}
\hline & $\begin{array}{c}\text { pH brine monitoring with nitric acid } \\
\text { (wine } \mathbf{A} \text { ) }\end{array}$ & $\begin{array}{c}\text { pH brine monitoring with sulphuric } \\
\text { acid }\end{array}$ \\
\hline (wine $\mathbf{B}$ )
\end{tabular}

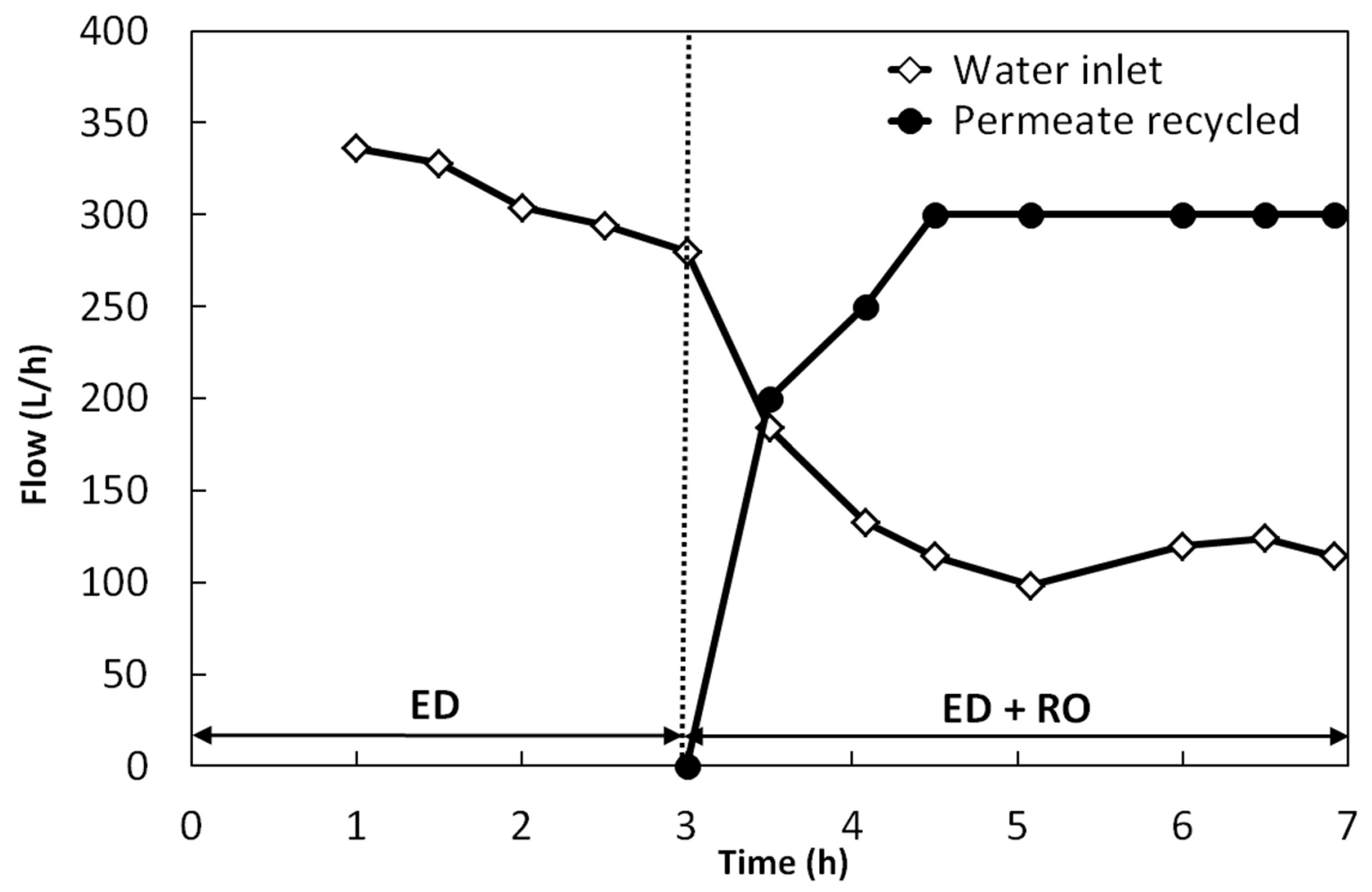

FIGURE 2

Evolution of water consumption and permeate and retentate flows when electrodialysis is coupled with reverse osmosis treatment of the brine and recycling of the permeate. 
time, the low conductivity of the permeate $(4.8$ to $5.2 \mathrm{mS}$ / $\mathrm{cm}$ ) allows it to be recycled as makeup water during the electrodialysis phase. This recycling leads to a major reduction in water consumption and the maintenance of brine composition ( 7.4 to $8.3 \mathrm{mS} / \mathrm{cm}$ ) when ED and RO are coupled, very close to the value obtained by ED alone (Fig. 3 and Table 3).

The compositions of the brine, permeate and retentate reveal the increase in potassium and tartaric acid concentrations in the retentate (Table 3). However, the ratios of their respective concentrations in the permeate and in the retentate illustrate the selectivity of reverse osmosis membranes toward these compounds. Tartaric acid is retained more highly by the membranes than potassium, leading to a permeate with a very low concentration of tartaric acid, thus favouring its recycling in the brine.

The relatively equal distribution of ethanol concentration in the three phases (brine, permeate, retentate) is indicative of the low selectivity of the reverse osmosis membrane used in relation to this compound at these concentrations (Table 3).

\section{Wastewater volumes and pollutant loads of tartaric stabilisation by ED coupled with reverse osmosis}

Table 4 indicates the water consumption balances, the organic load flows produced and the cleaning reagents used for the electrodialysis process coupled with brine treatment by reverse osmosis, including the different cleaning operations.

The total consumption of water during tartaric stabilisation by electrodialysis coupled with reverse osmosis (process and cleaning waters) was $5.5 \mathrm{~L} / \mathrm{hL}$ wine, with

TABLE 3

Composition of brine and wastes from electrodialysis coupled or not with brine treatment by reverse osmosis (wine A).

\begin{tabular}{lcccc}
\hline & ED without RO & \multicolumn{2}{c}{ ED + RO } & \\
\cline { 2 - 5 } & Brine & Brine & Permeate & Retentate \\
\cline { 2 - 5 } $\mathrm{pH}$ & 3.52 & 3.61 & 2.98 & 2.98 \\
Conductivity $(\mathrm{mS} / \mathrm{cm})$ & 6.82 & 7.84 & 5.03 & 17.18 \\
$\mathrm{COD}\left(\mathrm{g} \mathrm{O}_{2} / \mathrm{L}\right)$ & 8.763 & 13.168 & 8.744 & 22.07 \\
Tartaric acid $(\mathrm{g} / \mathrm{L})$ & 1.13 & 1.01 & 0.24 & 2.89 \\
Potassium $(\mathrm{g} / \mathrm{L})$ & 1.9 & 2.59 & 1.47 & 5.09 \\
Ethanol $(\mathrm{g} / \mathrm{L})$ & 1.62 & 3.38 & 2.99 & 3.81 \\
\hline
\end{tabular}

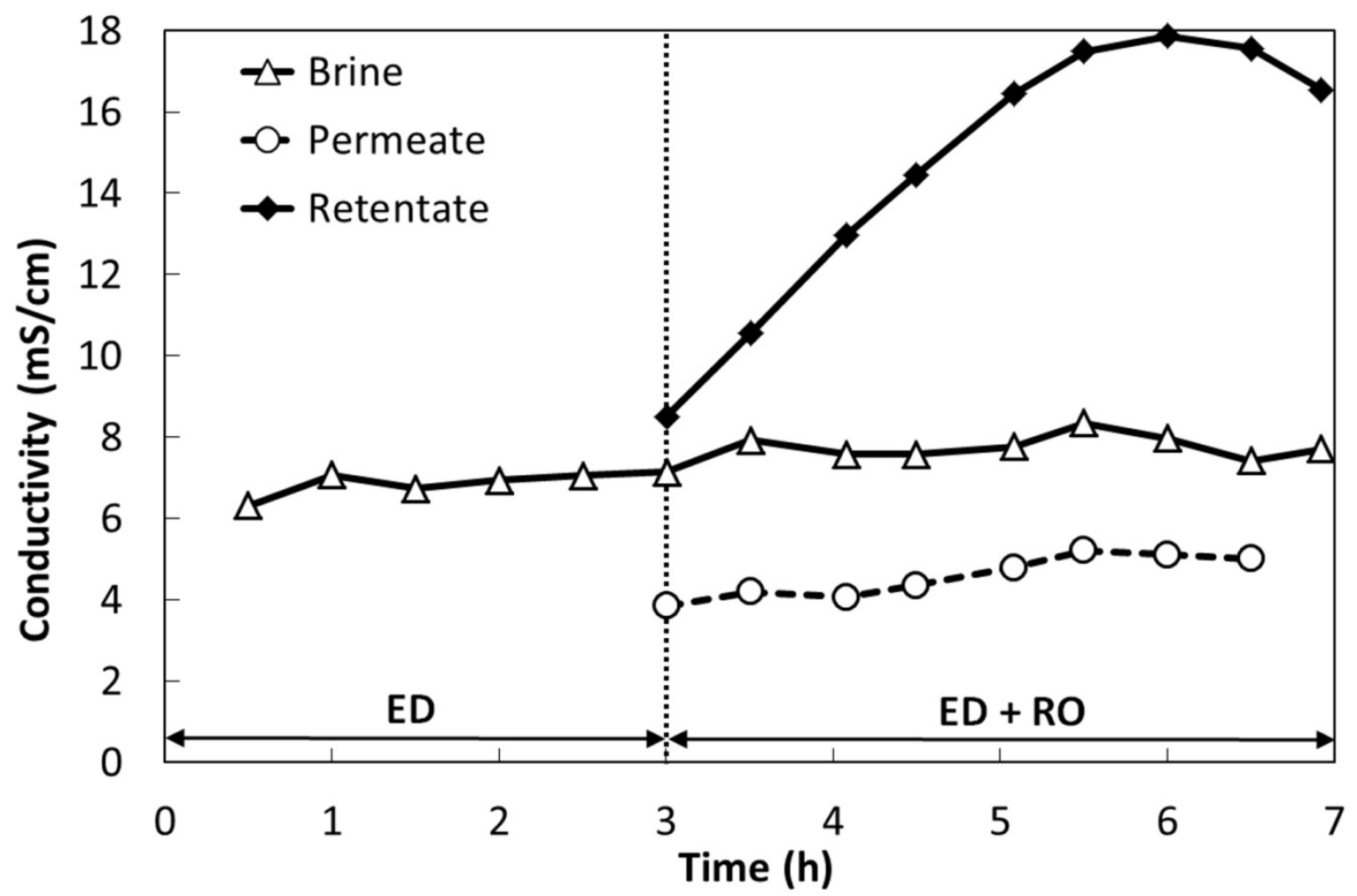

FIGURE 3

Evolution of the conductivity of the brine, permeate and retentate when electrodialysis is coupled with reverse osmosis treatment of the brine and recycling of the permeate. 
an organic load flow of $99.2 \mathrm{~g} \mathrm{COD} / \mathrm{hL}$ wine. Cleaning operations for electrodialysis and reverse osmosis equipment used $29 \%$ of the total water volume $(1.6 \mathrm{~L} / \mathrm{hL}$ wine) and produced only $13.4 \%$ of the quantity of COD evacuated (13.3 g COD/hL wine). A comparison of the total water consumption (process and cleaning waters) optimised in industrial facilities (coupling of electrodialysis/reverse osmosis) $-5.5 \mathrm{~L} / \mathrm{hL}$ wine, with data derived from tartaric stabilisation on the pilot and prototype scale without brine treatment -10 to $15 \mathrm{~L} / \mathrm{hL}$ wine (Moutounet \& Escudier, 1991), reveals the major progress made, leading to substantial savings in water. The reagents used are mainly nitric or sulphuric acid to maintain the $\mathrm{pH}$ of the brines and for cleaning operations, plus sodium hydroxide that is used exclusively to clean equipment (Table 4).

The electrical energy consumption measured during our study $-0.21 \mathrm{kWh} / \mathrm{hL}$ wine - corresponds to a continuous stabilisation treatment by electrodialysis (nominal wine flow: $30 \mathrm{hL} / \mathrm{h}$ ) at a stabilisation level of $18 \%$, and includes all of the operations (electrodialysis, reverse osmosis, cleaning operations). This consumption is much lower than that reported for discontinuous tartaric stabilisation (batch) of $0.58 \mathrm{kWh} / \mathrm{hL}$ (Gómez Benítez et al. 2002), as well as the one of $0.8 \mathrm{kWh} / \mathrm{hL}$ estimated by Low et al. (2008).

A comparison of water consumption and the emission of COD during the tartaric stabilisation of wines by electrodialysis measured in this study with that of vinification operations (Bories \& Sire, 2010) shows that tartaric stabilisation by electrodialysis represents $10.7 \%$ of the water consumption and $11.6 \%$ of the COD evacuated during white wine-type liquid-phase vinification (Table 5).

Water consumption during tartaric stabilisation by electrodialysis and reverse osmosis $(5.5 \mathrm{~L} / \mathrm{hL}$ wine) represents only about $6 \%$ of overall winery water consumption (100 1/hl wine) (Mourgues \& Maugenet, 1972; Maugenet, 1978; Picot, 1992; Duarte et al., 1998; Lemiere et al., 1998; Picot \& Cabanis, 1998; Rossi et al., 1998; Viaud et al., 1998; Sheridan et al., 2004; Colin et al., 2005; Rochard, 2005; Vogdt \& Schleestein, 2006). However, if we extend this comparison to the overall water consumption of the wine sector, where phytosanitary treatments represent 100 to $500 \mathrm{~L}$ water/ha/treatment (Heinzlé, 2007), or 20 to 40 $\mathrm{L}$ water/hL wine produced (10 treatments for a yield of 60 $\mathrm{hL}$ wine/ha), and vineyard irrigation in areas where water deficits exist represents 50 to $100 \mathrm{~mm} /$ ha (Deloire, 2008), requiring 800 to $1600 \mathrm{~L}$ water $/ \mathrm{hL}$ wine (yield: $60 \mathrm{hL} / \mathrm{ha}$ ), the water consumption for tartaric stabilisation $(5.5 \mathrm{~L} / \mathrm{hL}$ wine $)$

TABLE 4

Consumption of water, reagents and electrical energy and the organic load of waste (COD) during tartaric stabilisation by electrodialysis coupled with brine treatment by reverse osmosis.

\begin{tabular}{|c|c|c|}
\hline \multirow{4}{*}{ Water (L/hL wine) } & Retentates/Brines & 3.9 \\
\hline & CIP ED & 1.5 \\
\hline & CIP RO & 0.1 \\
\hline & Total & 5.5 \\
\hline \multirow{4}{*}{ Organic load (g COD/hL wine) } & Retentates/Brines & 85.9 \\
\hline & CIP ED & 13.1 \\
\hline & CIP RO & 0.2 \\
\hline & Total & 99.2 \\
\hline \multirow{4}{*}{ Nitric acid (L/hL wine) } & ED brines & 0.03 \\
\hline & CIP ED & 0.004 \\
\hline & CIP RO & 0.004 \\
\hline & Total & 0.038 \\
\hline \multirow{3}{*}{ Sodium hydroxide (L/hL wine) } & CIP ED & 0.014 \\
\hline & CIP RO & 0.004 \\
\hline & Total & 0.018 \\
\hline \multirow{2}{*}{ Electrical energy ( $\mathrm{kWh} / \mathrm{hL}$ wine) } & $\mathrm{ED}+\mathrm{RO}$ & 0.18 \\
\hline & $\mathrm{ED}+\mathrm{RO}+\mathrm{CIP}$ & 0.21 \\
\hline
\end{tabular}

TABLE 5

Water consumption and COD emission during vinification and tartaric stabilisation by electrodialysis and reverse osmosis.

\begin{tabular}{lcccc}
\hline & \multicolumn{3}{c}{ Vinifications * } & Electrodialysis + Ro \\
\cline { 2 - 4 } & White wine & $\begin{array}{c}\text { Rosé wine }+ \\
\text { Red/thermo }\end{array}$ & $\begin{array}{c}\text { Red wine } \\
\text { vatting }\end{array}$ & $\begin{array}{c}\text { (this study) } \\
\text { L water/L wine }\end{array}$ \\
g COD/L wine & 0.513 & 0.51 & 0.35 & $\mathbf{0 . 0 5 5}$ \\
\hline
\end{tabular}

* according to Bories and Sire, 2010. 
appears to be very low.

Tartaric stabilisation by cold treatment

Water consumption and production of wastewaters and residues during tartaric stabilisation by cold treatment

The total water consumption for tartaric stabilisation by cold treatment (washing of the tank and filter) was 1.54 and 1.88 $\mathrm{L} / \mathrm{hL}$ wine for the two sites studied (Table 6).

Fifty to $74 \%$ of the wastewater volume was produced when the filter was washed. The total organic load evacuated (washing water and DE) was 38.5 and $63.7 \mathrm{~g} \mathrm{COD} / \mathrm{hL}$ wine (Table 6). DE contains 67 to $78 \%$ of the total organic load emitted during tartaric stabilisation by cold treatment. The quantities of DE waste produced were 1 and $2.6 \mathrm{~g}$ of DE (wet weight $) / \mathrm{L}$ of wine treated.

Available data for wine filtration on diatoms indicate consumptions of 0.20 to $2 \mathrm{~g} \mathrm{DE} / \mathrm{L}$ wine (Ribéreau-Gayon et al., 1998), and of 1 to $1.40 \mathrm{~g} \mathrm{DE} / \mathrm{L}$ wine (Gómez Benítez et al., 2002; ERBSLÖH). Consumption of diatomaceous earth in oenology is close to that of filtration in food industries such as breweries, where the average consumption of kieselguhr varies from 1 to $2 \mathrm{~g} / \mathrm{L}$ of beer (Fillaudeau et al., 2008).

\section{Composition of wastewaters and residues}

Analyses of wastewater and residue composition in tartaric stabilisation by cold treatment were carried out for a white wine (Table 7) and a red wine (results not presented). White wines generally have a higher level of tartaric instability than red wines, implying a quasi-systematic tartaric stabilisation.

Washing waters from the white wine cold stabilisation tank are rich in tartaric acid $(15.5 \mathrm{~g} / \mathrm{L})$, which is present in the form of potassium hydrogen tartrate crystals, making up $52 \%$ of the COD (Table 7). Ethanol ( $2 \mathrm{~g} / \mathrm{L}$ ) represents $28.4 \%$ of the COD.

Analysis of the residual DE revealed that ethanol accounts for $71.8 \%$ of the COD retained in the soils, whereas tartaric acid accounts for only $1.5 \%$ of the COD. The ethanol present in the DE waste comes from the wine occluded by the DE that constitutes a part of the wine lost. On the basis of the quantities of ethanol $(0.055 \mathrm{~g} / \mathrm{g}$ wet soil $)$ and DE evacuated $(2.46 \mathrm{~g} / \mathrm{L}$ wine $)$ and the alcohol content of the wine $(11.2 \% \mathrm{vol} / \mathrm{vol})$, the wine lost in the diatomaceous earth would be $0.15 \mathrm{~L}$ wine $/ \mathrm{hL}$ of wine treated $(0.15 \% \mathrm{vol} / \mathrm{vol})$.

TABLE 6

Wastewater and residue balances for tartaric stabilisation of wines by cold treatment.

\begin{tabular}{|c|c|c|c|}
\hline \multirow[b]{2}{*}{ Wine treated } & \multirow[b]{2}{*}{ Volume (hL) } & \multirow{2}{*}{$\begin{array}{c}\text { Wine C } \\
520\end{array}$} & \multirow{2}{*}{$\begin{array}{c}\text { Wine D } \\
825\end{array}$} \\
\hline & & & \\
\hline \multirow{3}{*}{ Washing of tank } & Volume water/wine treated $(\mathrm{L} / \mathrm{hL})$ & 0.77 & 0.48 \\
\hline & COD washing water $\left(\mathrm{g} \mathrm{O}_{2} / \mathrm{L}\right)$ & 2.6 & 14.8 \\
\hline & $\mathrm{COD} / \mathrm{hL}$ wine $\left(\mathrm{g} \mathrm{O}_{2} / \mathrm{hL}\right)$ & 2.0 & 7.3 \\
\hline \multirow{3}{*}{ Washing of filter } & Volume water/wine treated $(\mathrm{L} / \mathrm{hL})$ & 0.77 & 1.39 \\
\hline & COD washing water $\left(\mathrm{g} \mathrm{O}_{2} / \mathrm{L}\right)$ & 8.75 & 10 \\
\hline & $\mathrm{COD} /$ filtered wine $\left(\mathrm{g} \mathrm{O}_{2} / \mathrm{hL}\right)$ & 6.73 & 13.9 \\
\hline \multirow{4}{*}{ Diatomaceous earth } & Soils used (g/hL wine) & $\mathrm{nm}$ & 73 \\
\hline & Wet soils produced ( $\mathrm{g} / \mathrm{hL}$ wine $)$ & 96 & 264 \\
\hline & $\operatorname{COD}\left(\mathrm{g} \mathrm{O}_{2} / \mathrm{kg}\right)$ & 310 & 160 \\
\hline & COD DE/filtered wine $\left(\mathrm{g} \mathrm{O}_{2} / \mathrm{hL}\right)$ & 29.8 & 42.4 \\
\hline \multirow{3}{*}{ Pollution balance } & Wastewater volumes (washing of tank + filter) $(\mathrm{L} / \mathrm{hL})$ & 1.54 & 1.88 \\
\hline & COD washing water $\left(\mathrm{g} \mathrm{O}_{2} / \mathrm{hL}\right)$ & 8.7 & 21.2 \\
\hline & COD washing water and $\mathrm{DE}\left(\mathrm{g} \mathrm{O}_{2} / \mathrm{hL}\right)$ & 38.5 & 63.7 \\
\hline
\end{tabular}

TABLE 7

Composition of washing waters (tank, filter) and diatomaceous earth during tartaric stabilisation by cold treatment (wine D).

\begin{tabular}{lccc}
\hline & $\begin{array}{c}\text { Washing water } \\
\text { cold tank }\end{array}$ & $\begin{array}{c}\text { Washing water } \\
\text { filter }\end{array}$ & $\begin{array}{c}\text { Diatomaceous earth } \\
\text { (*g/g wet DE) }\end{array}$ \\
\cline { 2 - 4 } $\mathrm{pH}$ & 3.62 & 5.76 & 3.83 \\
Conductivity $(\mathrm{mS} / \mathrm{cm})$ & 3.14 & 0.66 & 0.144 \\
$\mathrm{COD}\left(\mathrm{g} \mathrm{O}_{2} / \mathrm{L}\right)$ & 14.8 & 10.0 & $0.16^{*}$ \\
Ethanol $(\mathrm{g} / \mathrm{L})$ & 2.012 & 3.172 & $0.055^{*}$ \\
Tartaric acid $(\mathrm{g} / \mathrm{L})$ & 15.549 & 0.3 & $0.005^{*}$ \\
Potassium $(\mathrm{g} \mathrm{K} / \mathrm{L})$ & 4.223 & 0.023 & $0 *$ \\
\hline
\end{tabular}


This value is similar to the one given for wine filtration on kieselguhr (ERBSLÖH Geisenheim AG, Germany). In addition to the difficulties related to the elimination of used DE (composting, disposal), handling of the diatoms is subject to specific conditions when it is used for filtration (INRS, 1997).

Electrical energy consumption for tartaric stabilisation by cold treatment in the two wineries studied could not be measured specifically when the waste balances were drawn up as a result of the configuration of the facilities and other simultaneous activities. On the basis of wines stored in cellars at room temperature, electrical energy consumption was evaluated at between 1 and $1.7 \mathrm{kWh} / \mathrm{hL}$ (Langlois, 1992; Gómez Benítez et al., 2002). Electrical energy consumption for several cold treatment methods was evaluated by Low et al. (2008) at approximately $1 \mathrm{kWh} / \mathrm{hL}$ wine for wines stored in cellars at $+8^{\circ} \mathrm{C}$, which may minimise electrical energy consumption for cold stabilisation.

\section{CONCLUSIONS}

Tartaric stabilisation by an electromembrane process coupled with brine treatment by reverse osmosis generates environmental benefits at various levels: a very significant decrease in water consumption and a reduction in waste. Major progress was made as a result of the possibility of recycling permeates from reverse osmosis in electrodialysis, with a reduction of $65 \%$ of the overall water consumption compared to the basic electrodialysis process without brine treatment. In order to reach the final objective of zero waste, particularly by recycling retentate constituents (tartaric acid), additional studies are currently being done by the Eurodia Company.

Compared to other stages of wine production and vineyard cultivation, water consumption during the tartaric stabilisation of wines is of secondary importance, and its optimisation is an integral part of the approach to resource management, eco-processes and sustainable development.

Concerning waste, the main advantage of tartaric stabilisation by electrodialysis in comparison to cold treatment is the elimination of diatomaceous earth and its residues, the disposal of which is an increasing problem for wineries. Moreover, the loss of wine occluded in the diatomaceous earth does not occur in tartaric stabilisation with electromembranes, which obviously provides a competitive advantage in economic terms. The small quantity of dead volume of electrodialysis units, as well as the automated water-driven feed procedures for the wine at start-up and the automated procedures for terminating stabilisation treatment and for cleaning operations, limits wine volume losses, which eventually are similar to those observed for devatting wine using pumps.

Electrodialysis waste, which is characterised by a simple organic load (ethanol, tartaric acid and salts) and is biodegradable and not very concentrated, does not present any particular difficulty in terms of treatment with other waste from vinification, filtration or washing of the tanks and winemaking equipment. The reagents used in electrodialysis are products commonly found in most agro-food and winemaking industries, particularly for cleaning operations, and their consumption is low.
By reducing electrical energy consumption to one-eighth that of cold treatment, tartaric stabilisation by electrodialysis results in substantial energy savings. Progress made in the eco-design of tartaric stabilisation by electrodialysis, which notably includes coupling with brine treatment by reverse osmosis, contributes to reducing the environmental impact of wine production and to integrating it into an exemplary approach to sustainable development.

\section{LITERATURE CITED}

Blouin, J., 1982. Les techniques de stabilisation tartrique des vins par le froid. Connaissance Vigne Vin 1, 63-67.

Bories, A. \& Sire, Y., 2010. Impacts of winemaking methods on wastewaters and their treatment. S. Afr. J. Enol. Vitic. 1, 38-44.

Colin, T., Bories, A., Sire, Y. \& Perrin, R., 2005. Treatment and valorisation of winery wastewater by a new bio-physical process. Water Sci. Technol. 1, 99-106.

Cottereau, P., 1989. Etude et développement de membranes d'électrodialyse appliquées aux produits de la vigne. Thèse, Université Paris XII, France.

Deloire, A., 2008. Irrigation de la vigne. Synthèse [Online]. Available: www.obs-viti-cg34.com

Duarte, E.A., Martins, M.B., Ghira, J.P., Carvalho, E.C., Spranger, I., Costa, S., Leandro, M.C. \& Duarte, J.M., 1998. An integrated approach for assessing the environmental impacts of wineries in Portugal. In: Cemagref (ed.). $2^{\text {nd }}$ International specialized conference on winery wastewaters, May 1998, Bordeaux, France. pp 61-69.

Duarte, E.A., Reis, I.B. \& Martin, M.O., 2004. Implementation of an environmental management plan towards the global quality concept - A challenge to the winery sector. In: University of Barcelona (ed.). Proc. $3^{\text {rd }}$ International specialized conference on sustainable viticulture and winery wastes management, May 2004, Barcelona. pp 23-30.

ERBSLÖH. [Online]. Available: www.erbsloeh.com/fr/datenblatt/WEIN/ CelluFluxx_Flyer_TechnikTipp.pdf

Ferenczi, S., Asvany, A. \& Erczhegyi, L., 1982. Stabilisation des vins contre les précipitations tartriques par le froid. Bulletin O.I.V. 613, 203-220.

Fillaudeau, L., Bories, A. \& Decloux, M., 2008. Brewing, winemaking and distilling: an overview of wastewater treatment and utilisation schemes. In: Klemes, J., Smith, R. \& Kim, J.-K. (eds.). Handbook of water and energy management in food processing. Woodhead Publishing, Cambridge. pp 929-995.

Gómez Benítez, J., Palacios Macías, V.M., Pérez Rodriguez, L., Szekely Gorostiaga, P. \& Veas López, R., 2002. Estimación de los costes directos de la estabilización tartárica mediante tratamiento por frío, intercambio protónico y electrodiálisis. Tecnología del vino 6, 45-49.

Grenier, P., Racault, Y. \& Mékikdjian, C., 1998. Méthode simplifiée d'évaluation de la charge polluante d'une cave vinicole en période de vendanges. In: Cemagref (ed.). $2^{\text {nd }}$ International specialized conference on winey wastewaters, May 1998, Bordeaux, France. pp. 15-24.

Heinzlé, Y., 2007. Pulvérisation en viticulture durable. Choix du matériel et réglages. In : Institut Français de la Vigne et du Vin (ed.), Itinéraires 16, pp 1-28.

Hernández, P. \& Mínguez, S., 1997. Uso de resinas de intercambio iónico en enología. Estabilización tartárica. Revue Française d'Enologie 162, 32-35.

INRS, 1997. Fiche Toxicologique FT 232 Silice cristalline. Cahier de notes documentaires - Hygiène et sécurité au travail 168, $3^{\text {ème }}$ trimestre [Online]. Available: http://www.inrs.fr/inrs-pub/inrs01.nsf/inrs01_search_view/0F0F CAF635E69A70C1256CE8005B52F5/\$File/ft232.pdf 
Langlois, M., 1992. La stabilisation tartrique des vins en continu contact par le système Ingevins. Revue des Enologues 62, 25-30.

Lemiere, J.P., Cisse, Z., Olsson, A. \& Coquille, J.C., 1998. Bilan et analyse des flux polluants dans deux exploitations bourguignonnes au cours des vendanges. In: Cemagref (ed.). $2^{\text {nd }}$ International specialized conference on winey wastewaters, May 1998, Bordeaux, France. pp 41-49.

Low, L.L., O’Neill, B., Ford, C., Godden, J., Gishen, M. \& Colby, C., 2008. Economic evaluation of alternative technologies for tartrate stabilisation of wines. Int. J. Food Sci. Technol. 43, 1202-1216.

Marchal, R., Laigre, M., Jeandet, Ph., Legras, V. \& Robillard, B., 2009. Utilisation de CMC pour la stabilisation tartrique des vins blancs. Partie 1/2: La CMC en Enologie - Détermination expérimentale de la température de stabilité d'un vin. Revue des Enologues 133, 38-41.

Marchal, R., Laigre, M., Jeandet, Ph., Legras, V. \& Robillard, B., 2010. Utilisation de CMC pour la stabilisation tartrique des vins blancs. Partie 2/2 : Résultats expérimentaux. Revue des Enologues 134, 43-46.

Maugenet, J., 1978. Les eaux résiduaires dans les industries viti-vinicoles, leur origine et les possibilités de traitement. Revue Française d'Enologie 71, 23-29.

Moine-Ledoux, V., Perrin, A., Paladin, I. \& Dubourdieu, D., 1997. Premiers résultats de stabilisation tartrique de vins par addition de mannoprotéines purifiées (Mannostab). J. Int. Sci. Vigne Vin 1, 23-31.

Mourgues, J. \& Maugenet, J., 1972. Les eaux résiduaires de caves de vinification. Ind. Alim. Agric. 3, 261-273.

Moutounet, M. \& Escudier, J.L., 1991. Tartaric stabilisation of wines and electrodialysis: new prospects. The Australian Grapegrower \& Winemaker $332,19-21$.

Moutounet, M., Batlle, J.L., Saint-Pierre, B. \& Escudier, J.L., 1999 Stabilisation tartrique. Détermination du degré d'instabilité des vins. Mesure de l'efficacité des inhibiteurs de cristallisation. In: Tec \& Doc Edition (ed.). Proc. Enologie $996^{\mathrm{e}}$ Symposium international d'œnologie, Bordeaux. pp 531-534.

Moutounet, M., Bouissou, D. \& Escudier, J.-L., 2010a. Treatment effects of red wine tartrate stabilization by cellulose gum (carboxymethylcellulose). Infowine, Internet Journal of Viticulture and Enology [Online]. www. infowine.com

Moutounet, M., Bouissou, D. \& Escudier, J.-L., 2010b. Détermination du degré d'instabilité tartrique (DIT), principes et applications. Revue Française d'Enologie 242, 24-28.
Moutounet, M., Saint-Pierre, B., Batlle, J.L. \& Escudier, J.L., 1997. Le stabilisateur tartrique: principe et description du procédé. Revue Française d'Enologie 162, 15-17.

Peng, Z., Waters, E.J., Pocock, K.F. \& Williams, P.J., 1996. Red wine bottle deposits, II: Cold stabilization is an effective procedure to prevent deposit formation. Australian Journal of Grape and Wine Research 1, 1-5.

Picot, B., 1992. Pollution engendrée par les établissements vinicoles. Revue Française d'Enologie 134, 5-10.

Picot, B. \& Cabanis, J.C., 1998. Caractérisation des effluents vinicoles : évolution des charges polluantes de deux caves vinicoles du sud de la France sur deux cycles annuels. In: Cemagref (ed.). $2^{\text {nd }}$ International specialized conference on winey wastewaters, May 1998, Bordeaux, France. pp 312 317.

Rochard, J., 2005. In: Oenoplurimedia (ed.). Traité de viticulture et d'oenologie durables, Traitement d'épuration des effluents vinicoles, Chaintré, France. pp 221-241.

Ribéreau-Gayon, P., Glories, Y., Maujean, A. \& Dubourdieu, D., 1998. In: Dunod (ed.). Traité d'Oenologie, 2. Chapter 11: La clarification des vins par filtration et centrifugation. Chimie du vin, stabilisation et traitements. Paris. pp 402-403.

Rossi, A., Malpei, F. \& Padoani, L., 1998. Estimate of polluting loads in effluents of Italian North East wineries. In: Cemagref (ed.). $2^{\text {nd }}$ International specialized conference on winey wastewaters, May 1998, Bordeaux, France. pp 33-40.

Saint-Pierre, B., Battle, J.L., Escudier, J.L. \& Moutounet, M., 1998 L'instabilité tartrique des vins : problématique, évaluation, méthodes et techniques de stabilisation. In : Flanzy, C. (ed.). Enologie, fondements scientifiques et technologiques. Lavoisier Tech. \& Doc, Paris. pp 921-935.

Sheridan, C.M., Bauer, F.F., Burton, S. \& Lorenzen, L., 2004. A critical process analysis of wine production to improve cost, quality and environmental performance. In: University of Barcelona (ed.). Proc. $3^{\text {rd }}$ International specialized conference on sustainable viticulture and winery wastes management, May 2004, Barcelona. pp 31-38.

Viaud, M.N., Rochard, J., Desautels, F., Pluchart, D. \& Badie, F., 1998 Oeno 2000. Caractérisation des effluents vinicoles champenois In: Cemagref (ed.). $2^{\text {nd }}$ International specialized conference on winey wastewaters, May 1998, Bordeaux, France. pp 25-32.

Vogdt, J.E. \& Schleenstein, G., 2006. Wastewater characteristics from Chilean wineries. In: Proc. $4^{\text {th }}$ International specialized conference on sustainable viticulture: winery wastes and ecologic impact management, November 2004, Vina del Mar-Chile. pp 235-238. 